\title{
Influence of different levels of humic acid and esterified glucomannan on growth performance and intestinal morphology of broiler chickens
}

\author{
Seyed Mozafar S. M. Taklimi ${ }^{1}$, Hassan Ghahri $^{2}$, Mohammad Asadi Isakan ${ }^{1}$ \\ ${ }^{1}$ Department of Animal Physiology and Nutrition, Animal Science Research Institute, Karaj, Iran; \\ *Corresponding Author: seyedmozafar@yahoo.com, seyedmozafar@gmail.com \\ ${ }^{2}$ Urmia Branch Islamik Azad University, Urmia, Iran
}

Received 25 January 2012; revised 7 March 2012; accepted 2 May 2012

\begin{abstract}
A study was under taken to investigate the effect of dietary supplementations of humic acid and esterified glucomannan on broiler performance and the morphological measurements of small intestine. Two hundred and ten-day-old broiler chicks were weighed and randomly assigned to seven treatment groups in triplicate. The dietary treatments included (T1) control (basal diet without any additives), (T2) basal diets supplemented with $0.1 \%$ humic acid, (T3) basal diets supplemented with $0.2 \%$ humic acid, (T4) basal diets supplemented with $0.3 \%$ humic acid, (T5) basal diets supplemented with $0.1 \%$ esterified glucomannan, (T6) basal diets supplemented with $0.2 \%$ esterified glucomannan and (T7) basal diets supplemented with $0.3 \%$ esterified glucomannan. Different parameters including body weight gain (BWG), feed intake (FI), feed conversion ratio (FCR) and morphology of small intestine were evaluated during six weeks of experimental period. According to the results, at the end of experimental period, the highest average BWG were recorded in T4 group (fed with $0.3 \%$ humic acid), compared to control (T1) and other experimental groups $(p<0.05)$. Whereas, the highest body weight gain were observed during starter period in treatment 7 (fed with $0.3 \%$ esterified glucomannan) as compare to other experimental groups $(p<0.05)$. Statistically, feed intake remained unaffected during the experimental period in all the treatment groups. However, the lowest and the highest feed intake were observed numerically within treatments T4 and T1 with $4229.70 \mathrm{~g}$ and $4362.30 \mathrm{~g}$, respectively. Addition of dietary supplements used in the study appeared to have significant effect on
\end{abstract}

the morphology of the small intestine (jejunum mucosal development) of the broilers in different treatment groups. Compared to control group, the inclusion of either humic acid or esterified glucomannon decreased $(p<0.01)$ the crypt depth and increased villus height respectively $(p<0.05)$. Moreover, the diet supplements with humic acid $0.3 \%$ (T4) decreased crypt depth compared to esterified glucomannan and control. The dietary supplementations resulted in an increase in the villus height of intestinal mucosa of broilers. The increase in the villus height was associated with improvement of growth performance for both humic acid and esterified glucomannan. Based on our results it appeared that humic acid and esterified glucomannan can be used as a growth promoter in broiler diets and they can improve the gut health too.

Keywords: Broiler Chicks; Humic Acid; Esterified Glucomannan; Small Intestine

\section{INTRODUCTION}

Any attribute which can improve gastrointestinal tract health and immunity is extremely valuable in broiler diets. In last decades antibiotics had been used widely world-wide in poultry industry in order to prevent poultry pathogens and disease and to improve meat and egg production. However, with the unavoidable spread of bacterial resistance and cross resistance the use of antibiotics has been considered hazardous [1-3]. As consequences, many alternatives have been discussed including probiotics, prebiotics, herbal compounds and organic acids. Most of these substances exert their effects by influencing gastrointestinal flora and digestion processes. Among these alternatives the influence of humic acid has been studied extensively, and has been reported to have 
positive impact on the growth performance of birds. Humic acid defined as a class of compounds resulting from decomposition of organic matter, particularly plants are natural constituents of drinking water, soil and lignite. Humic acid inhibit bacterial and fungal growth, thus decrease levels of mycotoxins in feed [4,5]. Beneficial effects of humic acid are described concerning stress management [6], immune system [7,8], anti-inflammatory activity [9], antiviral properties [10], as well as prevention of intestinal diseases, mainly diarrhea in humans and animals. There are also reports that routine use of humic acid in the feed has a positive influence on growth of broilers $[11,12]$. The beneficial effect of humic acid on growth in different species of animals has been considered its capacity of changing gut physiology and interference in immunity [13]. Beside humic acid, yeast and yeast cultures have a long standing tradition of use in animal feeds. Yeast culture has been shown to affect intestinal mucosa development in poultry. In addition to growth performance, there are many trials showing that enrichment of diets with yeast could favorably improve the quality of edible meat from broilers. Yeast is also an excellent source of selenium and chromium; two trace minerals which may have positive effects of broiler health [14]. Since, 80's decades Oligosaccharide from outer cell wall component of live yeast (Saccharomyces cerevisiae), were introduced as a feed additive commercially in poultry industry. Since then, many studies have been conducted to investigate the effects of esterified glucomannan or it's derivatives on various parameters such as body weight, feed conversion ratio and feed intake of birds [15-17]. The objective of this study was to determine if experimental supplementation of different level of humic acid and esterified glucomannan in the young broiler chicken diet may improve performance and small intestine mucosal development of broiler chicks.

\section{MATERIALS AND METHOD}

\subsection{Birds and Experimental Design}

Two hundred and ten-day old (mixed sex) commercial Ross broiler chicks were randomly subjected to seven different treatment groups (three replicates of 10 chicks per dietary treatment). All birds were weighed (initial weight) individually after their arrival from the hatchery to the experimental farm, and on completion of the experiment day 42. The experiment was designed completely randomized to evaluate the effect of two different naturally available feed additives humic acid $(F H=$ Farmagu lator DRY ${ }^{T M}$ humate Yayalar Mah. Sanayi Cad. No. 29, Dolayoba, Pendik, Istanbul, Turkey), and esterified glucomannan, (Bio-Mos, USA) on small intestine mucosal development of digestive tract of birds. The birds were fed one of seven experimental treatments for 42 days. The experimental diets were as follows: $\mathrm{T} 1=$ Control (basal diet + no feed additives). $\mathrm{T} 2=\mathrm{T} 1+0.1 \%$, $\mathrm{T} 3=\mathrm{T} 1+0.2 \%$ and $\mathrm{T} 4=\mathrm{T} 1+0.3 \%$ humic acid and $\mathrm{T} 5=$ $\mathrm{T} 1+0.1 \%, \mathrm{~T} 6=\mathrm{T} 1+0.2 \%$ and $\mathrm{T} 7=\mathrm{T} 1+0.3 \%$ esterified glucomannan, respectively.

\subsection{Performance}

All chicks were reared under uniform management conditions with feed and water available ad libitum. Individual body weight gain (BWG), feed intake (FI), feed conversion ratio (FCR) of the birds were recorded at the onset of experiments and measured daily thereafter for each group.

\subsection{Small Intestine Mucosal Development Studies}

To study the mucosal development of small intestine of the chicks at the end of experimental period, 3 birds were selected randomly from each replicate and sacrificed and their histomorphology studied.

Gut morphology (jejunum) examinations were carried out according to the method which was described [18]. Jejunum samples were immersed in $4 \%$ formalin for 48 hrs. The processing consisted of serial dehydration, clearing, and impregnation with wax. Tissue sample was sectioned at a thickness of $7-8 \mu \mathrm{m}$, were cut by a microtome and were fixed on slides. A routine staining procedure was carried out using hematoxylin and eosin. The slides were viewed on a microscope. Visual observations of villus height, crypt depth were made at $10.25 \times$ magnification under an IMI microscope.

\subsection{Statistics}

All data were statistically analyzed by ANOVA using the SAS system [19]. Significant differences between the treatment means were compared by using Duncan Multiple Range test [20].

The statistical model used was

$$
Y i j=\mu+T i+e i j
$$

where,

$\boldsymbol{Y} \boldsymbol{i j}=$ observation in block $\boldsymbol{i}$ and treatment $\boldsymbol{j}, \boldsymbol{\mu}=$ Overall sample mean, $\boldsymbol{T} \mathbf{i}=$ Effect of treatment $\boldsymbol{i}, \boldsymbol{e} \boldsymbol{i} \mathbf{j}=$ Error.

\section{RESULTS}

The effect of different levels of humic acid and esterified glucomannan on body weight gain of broilers during the experimental period is shown in Table 1. A significant increase in BWG was recorded in birds which was fed with either humic acid or esterified glucomannan $(\mathrm{p}<0.05)$. According to the results, birds fed with $0.3 \%$ 
Table 1. Effects of humic acid and esterified glucomannan on mean BWG (g) of Broiler.

\begin{tabular}{cccc}
\hline Treatments & 0 - 21 days & 21 - 42 days & 0 - 42 days \\
\hline T1 (control) & $687.33^{\mathrm{c}}$ & $1459.67^{\mathrm{b}}$ & $2147.00^{\mathrm{b}}$ \\
T2 (0.1\% Humic acid) & $712.67 \mathrm{~b}^{\mathrm{c}}$ & $1554.67^{\mathrm{bc}}$ & $2267.33^{\mathrm{ab}}$ \\
T3 (0.2\% Humic acid) & $726.33^{\mathrm{abc}}$ & $1611.33^{\mathrm{a}}$ & $2337.67^{\mathrm{a}}$ \\
T4 (0.3\% Humic acid) & $723.33^{\mathrm{abc}}$ & $1650.33^{\mathrm{a}}$ & $2373.67^{\mathrm{a}}$ \\
T5 (0.1\% Live yeast) & $726.67^{\mathrm{abc}}$ & $1551.00^{\mathrm{ab}}$ & $2277.67^{\mathrm{ab}}$ \\
T6 (0.2\% Live yeast) & $740.67^{\mathrm{ab}}$ & $1622.67^{\mathrm{a}}$ & $2363.33^{\mathrm{a}}$ \\
T7 (0.3\% Live yeast) & $763.00^{\mathrm{a}}$ & $1602.00^{\mathrm{a}}$ & $2331.67^{\mathrm{a}}$
\end{tabular}

*Mean bears not common superscript are different significantly $(\mathrm{p}<0.05)$. a,b,c means: Values in the table shows with different superscripts are significantly different $(\mathrm{p}<0.05)$.

estrified glucomannan performed well at the early age, while with advancing age, humic acid had an increasing effect on overall performance of the birds. The highest and the lowest BWG was observed in T7 and T1 (763.00 vs $687.33 \mathrm{~g})$ during their initial growing phase $(0-21$ days), respectively, while, chicks in T4 $(0.3 \%$ humic acid) gained more body weight during the $2^{\text {nd }}$ phase of growth (21 - 42 days) as well during the whole experimental period $(\mathrm{p}<0.05)$.

As Table 2 indicates, feed intakes were not affected significantly by inclusions of different levels of either humic acid or esterified glucomannan in diets, during the experimental period. However, feed conversion ratio of the chicks in different treatment groups were significantly different with the presence of either humic acid or esterified glucomannan. According to the results presented in Table 3, the highest feed conversion ratio was observed in T4 (1.781), as compared to other experimental groups $(p<0.01)$. Overall results indicated that, birds fed diets with humic acid $(0.3 \%)$ had higher mean live weight gain, low feed intake and better feed conversion ratio.

Table 4 indicated that, feed additives used in this study had significantly effect on the villus height $(p<$ 0.05) of broiler chicks (Figure 1). All levels of humic acid and esterified glucomannan used had the ability to increase crypt depth $(\mathrm{p}<0.01)$. Where as, highest crypt depth were observed in T7, compared to other treatments. As evidence shows that, effects of humic acid and esterified glucomannan, is proposed to be due to their contents of anti bacterial agents and enhancement of multiplications of beneficial macroscopic bacteria and elimination of harmful bacteria in bird's digestive tract.

\section{DISCUSSION}

According to the results of this experiment, humic acid
Table 2. Effects of humic acid and esterified glucomannan on FI (g) of Broiler.

\begin{tabular}{cccc}
\hline Treatments & 0 - 21 days & 21 - 42 days & 0 - 42 days \\
\hline T1 (control) & 1088.00 & 3274.30 & 4362.30 \\
T2 (0.1\% Humic acid) & 1077.67 & 3217.30 & 4295.00 \\
T3 (0.2\% Humic acid) & 1032.67 & 3253.00 & 4285.70 \\
T4 (0.3\% Humic acid) & 1057.67 & 3172.00 & 4229.70 \\
T5 (0.1\% Live yeast) & 1042.00 & 3217.30 & 4274.30 \\
T6 (0.2\% Live yeast) & 1060.00 & 3257.00 & 4317.00 \\
T7 (0.3\% Live yeast) & 1062.00 & 3265.70 & 4327.70 \\
& $\mathrm{~ns}$ & $\mathrm{~ns}$ & $\mathrm{~ns}$ \\
\hline
\end{tabular}

ns $=$ Not significantly different $(\mathrm{p}<0.05)$.

Table 3. Effects of humic acid and esterified glucomannan on mean FCR.

\begin{tabular}{cccc}
\hline Treatments & 0 - 21 days & 21 - 42 days & 0 - 42 days \\
\hline T1 (control) & $1.583^{\mathrm{a}}$ & $2.243^{\mathrm{a}}$ & $2.031^{\mathrm{a}}$ \\
T2 (0.1\% Humic acid) & $1.512^{\mathrm{ab}}$ & $2.069^{\mathrm{b}}$ & $1.894^{\mathrm{b}}$ \\
T3 (0.2\% Humic acid) & $1.421^{\mathrm{b}}$ & $2.018^{\mathrm{bc}}$ & $1.833^{\mathrm{c}}$ \\
T4 (0.3\% Humic acid) & $1.462^{\mathrm{ab}}$ & $1.922^{\mathrm{c}}$ & $1.781^{\mathrm{d}}$ \\
T5 (0.1\% Live yeast) & $1.433^{\mathrm{b}}$ & $2.074^{\mathrm{b}}$ & $1.876^{\mathrm{c}}$ \\
T6 (0.2\% Live yeast) & $1.431^{\mathrm{b}}$ & $2.00^{\mathrm{bc}}$ & $1.826^{\mathrm{c}}$ \\
T7 (0.3\% Live yeast) & $1.392^{\mathrm{ab}}$ & $2.038^{\mathrm{b}}$ & $1.856^{\mathrm{c}}$ \\
& $*$ & $* *$ & $* *$ \\
\hline
\end{tabular}

${ }^{*}$ Mean bears not common superscript are different significantly $(\mathrm{p}<0.05)$; ${ }^{* *}$ Mean bears not common superscript are different significantly $(\mathrm{p}<0.01)$. $\mathrm{a}, \mathrm{b}, \mathrm{c}$ means: Values in the table shows with different superscripts are significantly different $(\mathrm{p}<0.05)$.

Table 4. Effects of humic acid and esterified glucomannan on Jejunum mucosal development of broiler.

\begin{tabular}{ccc}
\hline Treatments & Length of villiae $(\mathbf{m m})$ & Crypt depth $(\mathbf{m m})$ \\
\hline T1 (control) & $1.026^{\mathrm{b}}$ & $2.243^{\mathrm{a}}$ \\
T2 (0.1\% Humic acid) & $1.290^{\mathrm{ab}}$ & $2.069^{\mathrm{b}}$ \\
T3 (0.2\% Humic acid) & $1.383^{\mathrm{a}}$ & $2.018^{\mathrm{bc}}$ \\
T4 (0.3\% Humic acid) & $1.340^{\mathrm{a}}$ & $1.922^{\mathrm{c}}$ \\
T5 (0.1\% Live yeast) & $1.260^{\mathrm{ab}}$ & $2.074^{\mathrm{b}}$ \\
T6 (0.2\% Live yeast) & $1.293^{\mathrm{ab}}$ & $2.00^{\mathrm{bc}}$ \\
T7 (0.3\% Live yeast) & $1.246^{\mathrm{b}}$ & $2.038^{\mathrm{b}}$ \\
& $*$ & $* *$ \\
\hline
\end{tabular}

${ }^{*}$ Mean bears not common superscript are different significantly $(\mathrm{p}<0.05)$; ${ }^{* *}$ Mean bears not common superscript are different significantly $(\mathrm{p}<0.01)$. $\mathrm{a}, \mathrm{b}, \mathrm{c}$ means: Values in the table shows with different superscripts are significantly different $(\mathrm{p}<0.05)$. 


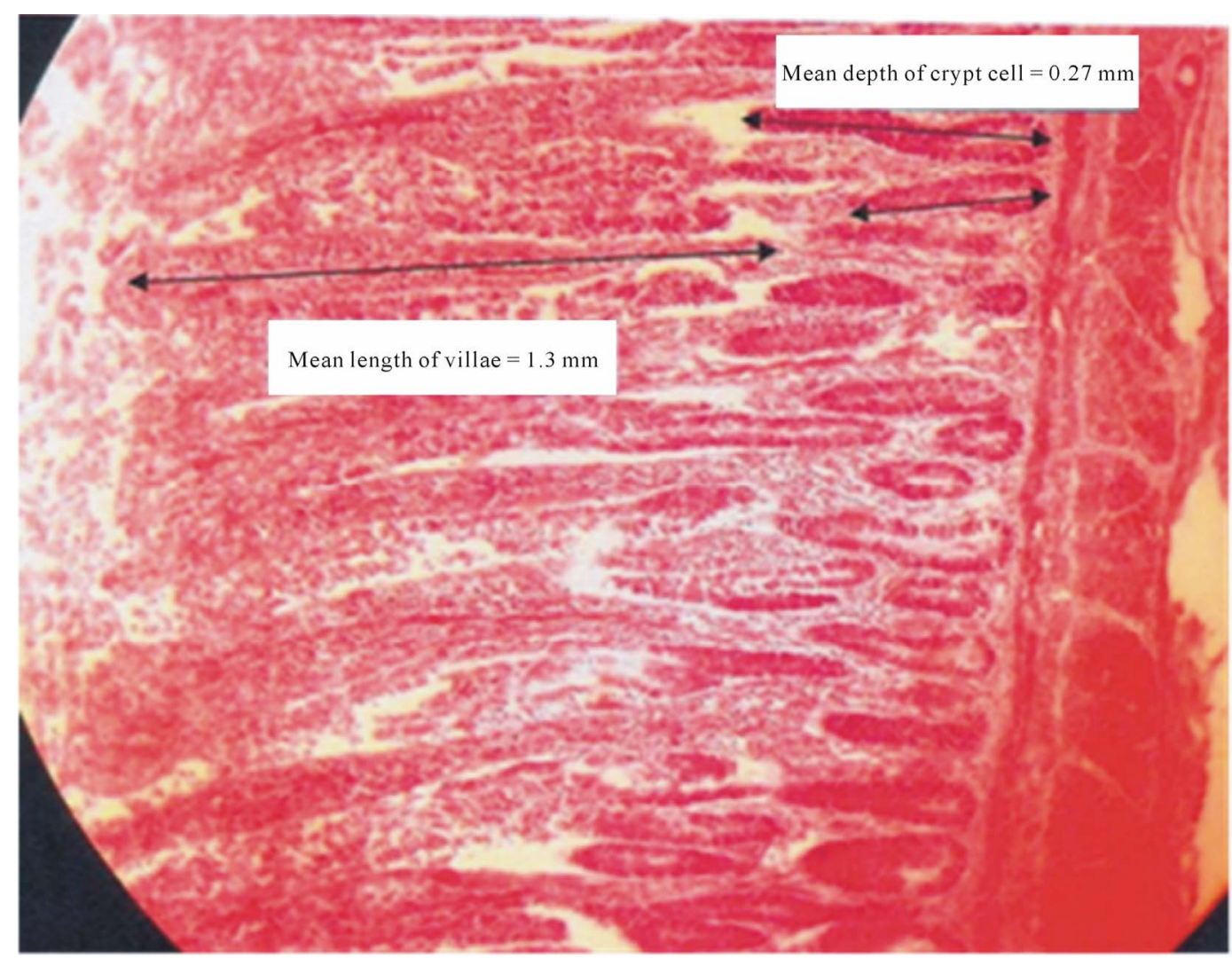

Figure 1. Vertical view of small intestine (jejunum, depth of crypt and length of villae, $100 \times$ magnifications).

and esterified glucomannan added as supplement in the feed had significantly effect on the performance of birds. This is in general agreement with a number of recent reports [14,12,21,22]. Nevertheless, Humic acid had higher effects on birds as compare to esterified glucomannan by means of 1) Ability to create protective layers over the epithelial mucosal membrane of digestive tract against the penetrations of toxic and other bacterial contaminated substances; 2) Will have ability to increase metabolism of protein and microbial carbohydrates based on catalyzing agents by bringing down the $\mathrm{pH}$ of small intestine; 3) It acts as detoxification agents in intestine (due to reducing power in absorption of nitrates, fluorites and heavy metals); 4) To increase immune receptors in digestive tract over preserving the beneficial pathogens [23]. There is some evidence that shows, by inclusions of esterified glucomannan in feed will increase bird's growth through reducing the harmful gut micro phlora by de-colonizing salmonella like bacteria, will increase bird's body weight, immune system, nutrient digestibility and gut health due to its effect on substituting harmful with beneficial gut micro phlora [17]. Esterified glucomannan will also shows its beneficial effect on birds through challenge with some un-expected growth inhibitors like aflatoxin, coccodiosis, heat stress and poor feed quality [17]. Feed intake was also affected numerically by inclusions of humic acid or esterified glucomannan at different levels throughout the experimental periods. Birds had offered diets containing $0.3 \%$ humic acid had lower levels of feed intake as compare to other experimental groups. This finding was in accordance with the reports of $[21,22]$. Feed conversion ratio was affected by inclusions of humic acid and esterified glucomannan throughout the experimental period. Best feed conversion ratio was observed in $0.3 \%$ humic acid supplemented groups, and it was in accordance with the reports of $[12,14]$. It is assumed that, due to the chemical compositions like, proteins, water soluble vitamins, digestive enzyme and many other immune stimulating agent and antibacterial substances in humic acid and in esterified glucomannan, they will have significant role in the of health and productivity of birds. This could be mainly attributed to their ability to change the gut micro flora (by increasing the concentrations of beneficial bacteria) in the intestine [24-26]. In the present study, inclusion of $0.3 \%$ humic acid in broiler diets had significantly better effects on bird performance. As reported earlier by $[27,28]$, humic acid and esterified glucomannan had significant effect on crypt depth of villiae in Jejunum of treated birds compared to non supplemented groups. It is obviously known that, growth of villiae will be depending on $\mathrm{pH}$, micro flora and toxic substances in the intes- 
tine. Though, humic acid will have the ability in reducing $\mathrm{pH}$ and concentration of harmful bacteria in intestine. There is evidence that humic acid could have positive effect on animal performances via digestive tract ecosystems [29]. Esterified glucomannan at higher dosage will increase height of villiae and crypt depth and inhalations of damaged villiae [30]. It also will secrete more enzymes in taller (projected) villiae, which finally will enhance the absorption and digestion of food particles. Moreover, esterified glucomannan will have effect to create protective layers on intestinal mucus, to inhibit penetrations of toxic substances and harmful bacteria in the gut.

To conclude, humic acid or esterified glucomannan displayed a greater efficacy as growth promoters for broilers and could be a suitable substitution as an alternative for antibiotics.

\section{REFERENCES}

[1] Andremont, A. (2000) Consequences antibiotic therapy to the intestinal ecosystem. Annales Françaises d'Anesthésie et de Réanimation, 19, 395-402. doi:10.1016/S0750-7658(00)90209-0

[2] Burgat, V. (1999) Residues of drugs of veterinary use in food. Revue Du Praticien, 41, 985-990.

[3] Maiolino, R., Fieretti, A., Menna, L.F. and Meo, C. (1992) Research on the efficiency of probiotics in diets for broiler chickens. International Journal of Poultry Sciences, 4, 488-492.

[4] HuminTech (2004) Huminfeed-tierfutterzusatze and veterinar medizin and huminsaure basierende produkte. Humintech@Humintech GmbH, Heerdter Landstr. 189/D, D40549 Dusseldrof, Germany.

[5] Riede, U.N., Zeck-Kapp, G., Freudenberg, N., Keller, H.U. and Seubert, B. (1991) Humate induced activation of human granulocytes. Virchows Archiv B Cell Pathology Zell-Pathologie, 60, 27-34. doi:10.1007/BF02899524

[6] Enviromate, T.M. (2002) Effects of humic acid on animals and humans (literature review and current research). Effects of humic acid. Environmate Inc., Forth Worth.

[7] Hooge, D.M. (2004) Meta-analysis of broiler chicken pen trials evaluating dietary mannan oligosaccharide. International Journal of Poultry Science, 3, 163-174. doi:10.3923/ijps.2004.163.174

[8] Loddi, M.M., Nakaghi, L.S.O., Edens, F., Tucci, F.M., Hannas, M.I., Moraes, V.M.B. and Ariki, J. (2002). Mannoligosaccharide and organic acids on intestinal morphology integrity of broilers evaluated by scanning electron microscopy. Proceedings of the 11th European Poultry Science Conference, Bremen, 6-10 September 2002, 121.

[9] Yang, H.L., Chiu, H.C. and Lu, F. (1996). Effects of humic acid on the viability and coagulant properties of human umbilical vein endothelial cells. American Journal of Hematology, 51, 200-206.
doi:10.1002/(SICI)1096-8652(199603)51:3<200::AID-AJ H4>3.0.CO;2-0

[10] Huck, T.A., Porter, N. and Bushell, M.E. (1991) Effect of humatees on microbial activity. Journal of General Microbiology, 137, 2321-2329.

[11] Eren, M., Deniz, G., Gezen, S.S. and Turkmen, I.I. (2000) Broyler yemlerine katilan humatlarin besi performansi serum mineral konsantrasyonu ve kemikku lu u zerine etkileri. Ankara Univ. Vet. Fak. Derg., 47, 255-263.

[12] Kocabagli, N., Alp, M., Acar, N. and Kahraman, R. (2002) The effects of dietary humate supplementation on broiler growth and carcass yield. Poultry Science, 81, 227-230.

[13] Mayhew, L. (2004) Humic substances in biological agricultural system. Acers, 34, 1-2.

[14] Celick, K., Denli, M., Erturk, M., Ozturkcan, O. and Doran, F. (2008) Evaluation of dry yeast saccharomyces cerevisiae in the feed to reduce aflatoxin B1 (AFB1) residues and toxicity to japonica quails (Coturnix Japonica). International Journal for Vitamin and Nutrition Research, 20, 245-250.

[15] Parks, C.W., Grims, J.L., Ferket, P.R. and Fairchild, A.S. (2001) The effect of mannan-oligosaccharides, bambermycins and virginiamycin on performance of large white male market turkeys. Poultry Science, 80, 718-723.

[16] Raju, M.V.L.N. and Dewegowda, G. (2000) Influence of esterified glucomannon on performance and organ morphology, serum biochemistry and haematology in broiler exposed to individual and combined mycotoxicosis (aflatoxin, ochratoxin and T-2 toxin). British Poultry Science, 41, 640-650. doi:10.1080/713654986

[17] Spring, P., Wenk, C., Dawson, K.A. and Newman K.E. (2000) The effect of dietary mannon oligosaccharides on caecal parameters and the concentrations of enteric bacteria in the ceca challenged broiler chickens. Poultry Science, 79, 205-211.

[18] Iji, P.A., Hughes, R.J., Choct, M. and Tivey, D.R. (2001) Intestinal structure and functional of broiler chicks on wheat based diets supplemented with a microbial enzyme. Asian-Australasian Journal of Animal Sciences, 14, 5460.

[19] SAS Institute (1998) SAS user's guide: Version 9.1 ed. SAS Institute Inc., Cary.

[20] Basiri, A. (2006) Experimental analysis in agricultural science. Shiraz University Publications, Shiraz.

[21] Gao, J., Zhang, H.J., Yu, S.H., Wu, S.G., Yoon, I., Quigley, J., Gao, Y.P. and Qi, G.H. (2008) Effect of yeast culture in broiler diets on performance and immunomodulatory functions. Poultry Science, 87, 1377-1384. doi:10.3382/ps.2007-00418

[22] Yoruk, M.A., Gu, M., Hayirli, A. and Macit, M. (2004) Effects of supplementation of humate and probiotic on egg production and quality parameters during the late laying period in hens. Poultry Science, 83, 84-88.

[23] Rath, N.C., Huff, W.E. and Huff, G.R. (2006) Effect of humic acid on broiler chickens. Poultry Science, 85, 410414.

[24] Oyofo, B.A., Deloach, J.R., Corrier, D.E., Norman, J.O., 
Ziprin R.L. and Mollenhauer, H.H. (1989) Prevention of Salmonella typhimurium colonization of broilers with D-mannose. Poultry Science, 68, 1357-1360. doi:10.3382/ps.0681357

[25] Savage, T.F., Nakaue, H.S. and Holms, Z.A. (1985) Effects of feeding live yeast culture on market turkey performance and cooked meat characteristics. Nutrition Reports International, 31, 695-703.

[26] Schepetkin, I.A., Khlebnikov, A.I., Ah, S.Y., Woo, S.B., Jeong, C.S., Klubachuk, O.N. and Kwon, B.S. (2003) Characterization and biological activities of humic substances from mumie. Journal of Agricultural and Food Chemistry, 51, 5245-5254. doi:10.1021/jf021101e

[27] Santin, E., Maiorka, A., Macari, M., Grecco, M., Okada, T.M. and Myasaka, A.M. (2001) Performance and intestinal mucosa development of broiler chickens fed diets containing Saccahromyces cerevisiae cell wall. The Jour- nal of Applied Poultry Research, 10, 236-244.

[28] Zhang, A.W., Lee, B.D., Lee, S.K., An, G.H., Song, K.B. and Lee, C.H. (2005) Effects of yeast (Saccharomyces cerevisiae) cell components on growth performance, meat quality and ileal mucosa development of broiler chicks. Poultry Science, 84, 1015-1021.

[29] Shermer, C.L., Maciorowski, K.G., Baily, C.A., Byers, F.M. and Ricke, S. (1998) Caecal metabolites and microbial populations in chickens consuming diets containing a mined humate compound. Journal of the Science of Food and Agriculture, 77, 479-486. doi:10.1002/(SICI)1097-0010(199808)77:4<479::AID-JS FA607>3.0.CO;2-L

[30] Hampson, D.J. (1986) Alterations in piglet small intestinal structure at weaning. Research in Veterinary Science, 40, 32-40. 